\title{
ENZYME ACTIVITY IN SOYBEAN SEEDS PRODUCED UNDER FOLIAR APPLICATION OF MANGANESE
}

\author{
Atividade enzimática em sementes de soja produzidas sob aplicação de manganês via foliar
}

\author{
Everson Reis Carvalho ${ }^{1}$, João Almir Oliveira ${ }^{2}$, \\ Édila Vilela de Resende Von Pinho ${ }^{2}$, Jaime Costa Neto ${ }^{3}$
}

\begin{abstract}
Several factors affect the quality of soybean seeds, including the mineral nutrition of plants. Manganese (Mn) is an important nutrient because it has as one of its functions the enzyme activation. The aim of this study was to evaluate enzyme activity in seeds of soybean cultivars produced with foliar application of different doses of Mn. The experiment was conducted at the Universidade Federal de Lavras (UFLA) (Federal University of Lavras) in randomized blocks with three replications and $4 \times 4 \times 2$ factorial arrangement consisting of four soybean cultivars, two conventional and its genetically modified RR derived (BRS Celeste and BRS Baliza RR; BRSGO Jataí and BRS Silvânia RR), four doses of Mn via foliar application (0; 200; 400 and $\left.600 \mathrm{~g} \mathrm{Mn} \mathrm{ha}^{-1}\right)$ and two stages of application $\left(\mathrm{R}_{1}\right.$ or $\mathrm{R}_{3}$ ). In the seeds, the expressions of the enzymes esterase (EST), malate dehydrogenase (MDH), alcohol dehydrogenase $(\mathrm{ADH})$, superoxide dismutase (SOD), peroxidase (PRX) and isocitratelyase (ICL) were determined. For evaluation of physiological quality, the germination test and emergence speed index (ESI) were performed. The Mn content in the seeds was also determined. The expression of the enzymes EST, SOD, PRX and ICL in soybean seeds are affected by foliar application of Mn, regardless of the stages of application. In the seeds of the cultivars that showed better physiological quality, Celeste and Baliza RR, greater expressions of the enzymes ADH and ICL and lower expressions of MDH and of PRX were observed.
\end{abstract}

Index terms: Enzymes, Glycine max, quality, micronutrients.

\section{RESUMO}

Diversos fatores afetam a qualidade das sementes de soja, dentre eles a nutrição mineral das plantas. O manganês (Mn) é um nutriente importante por ter como uma de suas funções a ativação enzimática. O objetivo, neste trabalho, foi avaliar a atividade enzimática em sementes de cultivares de soja, produzidas com aplicação foliar de diferentes doses de Mn. O experimento foi conduzido na Universidade Federal de Lavras (UFLA), em blocos casualizados, com três repetições e esquema fatorial 4 x 4 x 2 , sendo quatro cultivares de soja, duas convencionais e suas derivadas transgênicas RR (BRS Celeste e BRS Baliza RR; BRSGO Jataí e BRS Silvânia RR), quatro doses de Mn via foliar (0; 200; 400 e $\left.600 \mathrm{~g} \mathrm{Mn} \mathrm{ha}^{-1}\right)$ e dois estádios de aplicação $\left(\mathrm{R}_{1}\right.$ ou $\left.\mathrm{R}_{3}\right)$. Nas sementes, foram determinadas as expressões das enzimas esterase (EST), malato desidrogenase (MDH), álcool desidrogenase (ADH), superóxido dismutase (SOD), peroxidase (PRX) e isocitrato liase (ICL). Para avaliação da qualidade fisiológica foram realizados os testes de Germinação e de Indice de velocidade de emergência (IVE). Determinou-se, também, o teor de Mn nas sementes. A expressão das enzimas EST, SOD, PRX e ICL em sementes de soja são influenciadas pela aplicação de Mn via foliar, independente do estádio de aplicação. Nas sementes das cultivares, as quais apresentaram melhor qualidade fisiológica, Celeste e Baliza RR, foram constatadas maiores expressões das enzimas ADH e ICL e menores expressões de MDH e de PRX.

Termos para indexação: Enzimas, Glycine max, qualidade, micronutrientes.

\section{INTRODUCTION}

Soybean seeds with high physiological quality are increasingly demanded and valued because fields planted with high vigor seeds tend to have high productive rates (Kolchinski, Schuch; Peske, 2005). Scheeren et al. (2010) observed that yield per area from high vigor seed lots may be $9 \%$ greater than low vigor ones. Various factors affect soybean seed quality, among them mineral nutrition affects the production of metabolites necessary for development of fruits and seeds. As for seeds, it is necessary that accumulation of reserves occurs adequately because the initial development of seedlings depends on these substances (Veiga et al., 2010). Mondo et al. (2012) found that the correlation between fertility and physiological potential of the seed is relevant for soybean seed technology.

Among these nutrients, manganese $(\mathrm{Mn})$ is important because it plays a fundamental role in cellular elongation; Mn deficiency may inhibit synthesis of lipids and secondary metabolites, and it is linked to the lignification process (Malavolta; Vitti; Oliveira, 1997;

\footnotetext{
${ }^{1}$ Universidade Federal de Lavras/UFLA - Departamento de Agricultura/DAG - Cx. P. 3037 - $37200-000$ - Lavras - MG - Brasil eversonreiscarvalho@hotmail.com

2Universidade Federal de Lavras/UFLA - Departamento de Agricultura/DAG - Lavras - MG - Brasil

${ }^{3}$ Syngenta Seeds Ltda - Uberlândia - MG - Brasil

Received in march 14, 2014 and approved in july 07, 2014
} 
Malavolta, 2006). Mn is essential to chlorophyll synthesis and its main function is related to enzyme activation (Dechen; Nachtigall, 2006). Mann et al. (2002) observed increases in yield, germination, vigor and protein and oil contents in soybean seeds as a result of Mn use, with doses of 3.5 and $7.0 \mathrm{~kg} \mathrm{Mn} \mathrm{ha} \mathrm{kg}^{-1}$ to soil and 150 to $600 \mathrm{~g} \mathrm{Mn} \mathrm{ha}^{-1}$ with foliar application in different stages development $\left(\mathrm{V}_{4}, \mathrm{~V}_{8}\right.$ and $\left.\mathrm{V}_{10}\right)$.

This micronutrient plays an important role in redox processes, such as in electron transport in photosynthesis and in detoxification of oxygen free radicals (Raychaudhuri, 2000). This fact is relevant in the cell detoxification process to avoid oxidative damages because it converts potentially dangerous products of the reactive oxygen species (ROSs). The excessive quantity of reactive oxygen species (ROSs) limits plant growth and development through oxidation of lipids of membranes or other molecules (Forman; Maiorino; Ursini, 2010). The concentration of ROSs is maintained at non-toxic levels by means of antioxidant mechanisms to avoid damages (Moller; Jensen; Hansson, 2007), and plants respond to the increase of ROSs with acceleration of enzymatic and non-enzymatic antioxidant processes (Alscher, Erturk; Health, 2002). Plants developed a complex antioxidant system for restricting the harmful effects of the ROSs (El-Shabrawi et al., 2010), which constitutes the primary defense against free radicals generated under stress conditions. For example, the superoxide dismutase (SOD) enzyme catalyzes dismutation of the superoxide radical $\left(\mathrm{O}_{2}{ }^{\bullet}\right)$ into $\mathrm{H}_{2} \mathrm{O}_{2}$ and $\mathrm{O}_{2}$ (Deuner et al., 2011) and the peroxidases (PRX) are specialized in removal of $\mathrm{H}_{2} \mathrm{O}_{2}$ (Moller, Jensen; Hansson, 2007).

Some enzymes contain $\mathrm{Mn}$ in their structure, one of them is superoxide dismutase (Mn-SOD), which acts toward neutralization of superoxides (Raychaudhuri, 2000) and, therefore, protects membranes and proteins against oxidation. The Mn-SODs do not exercise their functions in the absence of the $\mathrm{Mn}$ atom at their active site (Alscher, Erturk; Health, 2002). Furthermore, Mn is also a cofactor of peroxidases (Malavolta, 2006). Ávila et al. (2012) found that the activities of antioxidant agents showed a trend toward increase throughout aging of soybean seeds, contrary to the trend of viability and vigor.

Studies that relate plant mineral nutrition and enzyme activity in the soybean seeds produced are scarce. Thus, the aim of this study was to evaluate enzyme activity in seeds of soybean cultivars produced with foliar application of different doses of Mn.

\section{MATERIAL AND METHODS}

The trial was conducted in the experimental field of the Agriculture Department of the Universidade Federal de Lavras (UFLA) (Federal University of Lavras) in Lavras, MG, Brazil, in the south of Minas Gerais, latitude $21^{\circ} 14^{\prime} \mathrm{S}$, longitude $45^{\circ} 00^{\prime} \mathrm{W}$ Gr. and $918 \mathrm{~m}$ altitude. The climate is characterized as Cwa in the Köppen climate classification, rainy, temperate (mesothermal), with dry winter and rainy summer and subtropical (Dantas; Carvalho; Ferreira, 2007).

By means of soil chemical analysis $(0.00-0.20$ $m$ depth sample)of the experimental area (Dystroferric Red Latossol - Rhodic Eutrudox), $5.0 \mathrm{mg} \mathrm{dm}^{-3}$ of $\mathrm{Mn}$ (Mehlich 1) was observed, a content classified as low, since the level considered as critical by Ribeiro, Guimarães and Alvarez, (1999) is $8.0 \mathrm{mg} \mathrm{dm}^{-3}$. In soil preparation, plowing and disking was performed and opening of a furrow was performed mechanically. In the planting furrow, $400 \mathrm{~kg} \mathrm{ha}^{-1}$ of the fertilizer formulation NPK 04-30-10 was applied (Ribeiro; Guimarães; Alvarez, 1999).

The soybean cultivars used were two conventional (non-genetically modified) varieties and its genetically modified RR (Roundup Ready ${ }^{\circ}$, event GTS 40-3-2) corresponding (derived), tolerant to glyphosate herbicide, according to Gris et al. (2010), with the cultivar pairs being: BRS Celeste and BRS Baliza RR, BRSGO Jataí and BRS Silvânia RR. For sowing, the seeds were treated with the fungicide formulation Carbendazin + Thiram and inoculated with Bradyrhizobium japonicum, peat inoculants, in the proportion of 1,200,000 bacteria per seed. Sowing was performed on November 12, thinning at 15 days after seedling emergence, maintaining 15 plants per meter, 300,000 plants per hectare. The experimental plots consisted of 4 rows of plants of 5 -meter length, spaced at $0.5 \mathrm{~m}$, with the two center rows considered as useful, disregarding $0.5 \mathrm{~m}$ at each end. Glyphosate herbicide was not used for weed control, only Fluazifop-P-butyl + Fomesafen was applied. In plant health management, the fungicides Azoxystrobin + Cyproconazole and Thiophanate-methyl were used, and the insecticides Gamma-cyhalothrin and Beta-cyfluthrin + Imidacloprid.

Foliar application of $\mathrm{Mn}$ was performed at four doses: 0, 200, 400 and $600 \mathrm{~g} \mathrm{Mn} \mathrm{ha}^{-1}$, with single application together with vegetable oil adjuvant. For the $0 \mathrm{~g} \mathrm{Mn} \mathrm{ha}^{-1}$ dose, water was applied and, in the others, the Mn source used was a commercial product with a guarantee of water-soluble $\mathrm{Mn}$ of $137.50 \mathrm{~g} \mathrm{~L}^{-1}$. Foliar $\mathrm{Mn}$ 
applications were performed in the $\mathrm{R}_{1}$ plant development stage, beginning of flowering; or $\mathrm{R}_{3}$, beginning of pod formation (Fehr et al., 1971), and a $\mathrm{CO}_{2}$ pressurized $\left(2.8 \mathrm{kgf} \mathrm{cm}^{-2}\right)$ backpack sprayer was used, with spray solution consumption of $200 \mathrm{~L} \mathrm{ha}^{-1}$. The plot was protected by plastic sheeting for drift control at the time of application.

Harvest was performed manually, with plants between $\mathrm{R}_{7}$, physiological maturity, and $\mathrm{R}_{8}$, full maturity (Fehr et al., 1971), seeds with an approximate moisture content of $25 \%$. Drying was performed in the sun, until the seeds reached moisture content $13 \%$ (wet basis). A stationary mechanical plot thresher was used and analyses were performed on the group of seeds retained in the screens of a 5.5 and $6 \mathrm{~mm}$ circular sieve.

For analysis of enzyme expression, 50-seed samples was used for each field replication and, from these, the duplicates for the gels were withdrawn. For such analysis, the seeds were treated with Carbendazim + Thiram and then ground, adding liquid nitrogen and polyvinylpyrrolidone (PVP) antioxidant, and were then stored at $-86^{\circ} \mathrm{C}$. Before extraction, the samples were washed for oil removal. For that purpose, $600 \mu \mathrm{L}$ of a solution with $50 \%$ diethyl ether $+50 \%$ water was used, with homogenization and a 30-minute rest in ice for later centrifuging at $14,000 \mathrm{rpm}$ for $30 \mathrm{~min}$ at $4^{\circ} \mathrm{C}$, discarding the supernatant. After extraction and discontinuous electrophoresis, the gels were revealed for the enzymes isocitrate lyase (ICL; EC 4.1.3.1), according to Martins et al. (2000) with modifications, esterase (EST; EC 3.1.1.1), malate dehydrogenase (MDH; EC 1.1.1.37), alcohol dehydrogenase (ADH; EC 1.1.1.1), superoxide dismutase (SOD; EC 1.15.1.1) and peroxidase (PRX; EC 1.11.1.7), according to Alfenas et al. (2006).

The Mn content in the seeds was determined (Malavolta, Vitti; Oliveira 1997) at the Chemistry Department of UFLA. For evaluation of the seed physiological quality, the following tests with 4 replications of 50 seeds per block (In the field) were performed: germination test with counting at 5 days after sowing, with the results expressed in percentage of normal seedlings (Brasil, 2009); and emergence speed index (ESI), with sowing performed in a soil + sand (2:1) substrate, moistened to $60 \%$ field capacity in plastic trays, kept in a plant growth chamber at $25^{\circ} \mathrm{C}$, in an alternating (12-hour) light and dark system. Daily evaluations were made in regard to number of emerged seedlings, until stabilization, for calculation of ESI (Maguire, 1962).

A randomized block experimental design (RBD) was used with three blocks in the field. Treatments were analyzed in a $4 \times 4 \times 2$ factorial arrangement involving four soybean cultivars, four doses of Mn via foliar application, and two application stages. Evaluation of the enzyme profiles was made as based on the presence, absence and intensity of bands. Data on physiological quality and Mn content in the seeds were subjected to analysis of variance with the assistance of the Sisvar ${ }^{\circledR}$ software (Ferreira, 2011) at 5\% probability by the F test. When pertinent, the mean values were compared using the Scott-Knott test at $5 \%$, or polynomial regression analyses were performed with the choice of mathematical models significant at $5 \%$, with a greater value of the coefficient of determination.

\section{RESULTS AND DISCUSSSION}

\section{Esterase}

Differences were verified in the expression of the enzyme esterase (EST) in seeds subjected to different treatments (Figure 1). In the absence of foliar application of $\mathrm{Mn}$, treatments 1 and 2, lower EST activity was observed in soybean seeds compared to the treatments in which there was foliar application of Mn. The main function of $\mathrm{Mn}$ is related to enzyme activation (Dechen; Nachtigall, 2006).

A greater increase in expression of the enzyme EST with foliar application of Mn was observed in seeds of the cultivars Celeste and Jataí (Figure 1), mainly for Jataí seeds which may be indicative of mineral nutrition and genotype interaction. In this same cultivar, the greatest differences were observed in the Mn contents in the seeds between the dose of $0 \mathrm{~g} \mathrm{Mn} \mathrm{ha}^{-1}$ and the others with foliar application of Mn, principally with $400 \mathrm{~g} \mathrm{Mn}$ $\mathrm{ha}^{-1}$. For the Jataí cultivar the initial slope of the Mn curve was greater in relation to the others cultivars (Figure 2a).

An increase was seen in EST expression (Figure 1) and of the Mn content (Figure 2a) in seeds originating from plants subjected to foliar fertilization with the micronutrient. This fact may be associated with the increase of germination of the seeds as a result of foliar application of Mn (Figure 2b). EST is involved in lipid breakdown during the seed germination process. This process is relevant for renewed growth of the embryonic axis, especially in seeds rich in lipids, as is the case of soybeans (Veiga et al., 2010). 

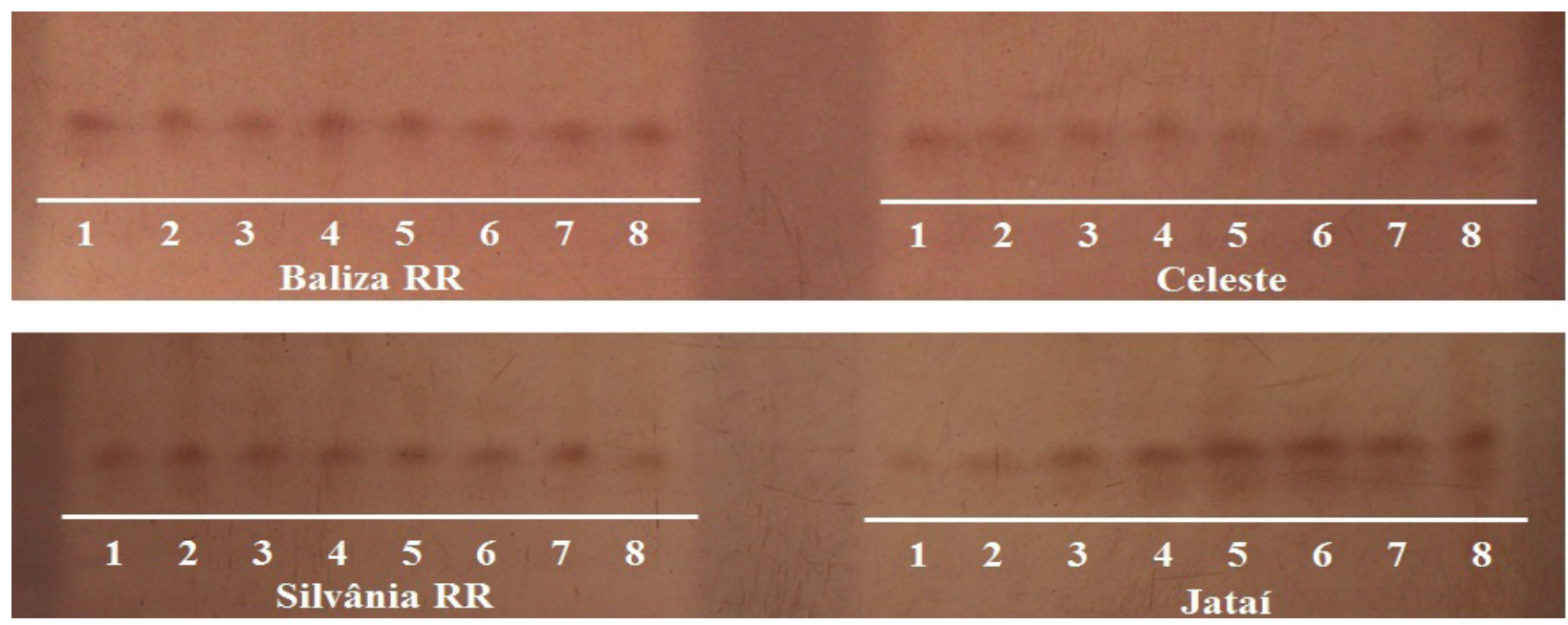

Figure 1 - Enzyme patterns of soybean seeds of the cultivars Baliza RR and Celeste, Silvânia RR and Jataí produced under different doses and stages for foliar application of Mn, revealed for esterase (EST), with: 1(0, R1), 2(0, R3), 3 (200, R1), 4 (200, R3), 5(400, R1), 6 (400, R3), 7 (600, R1) and 8 (600 g Mn ha' ${ }^{-1}$ R3).
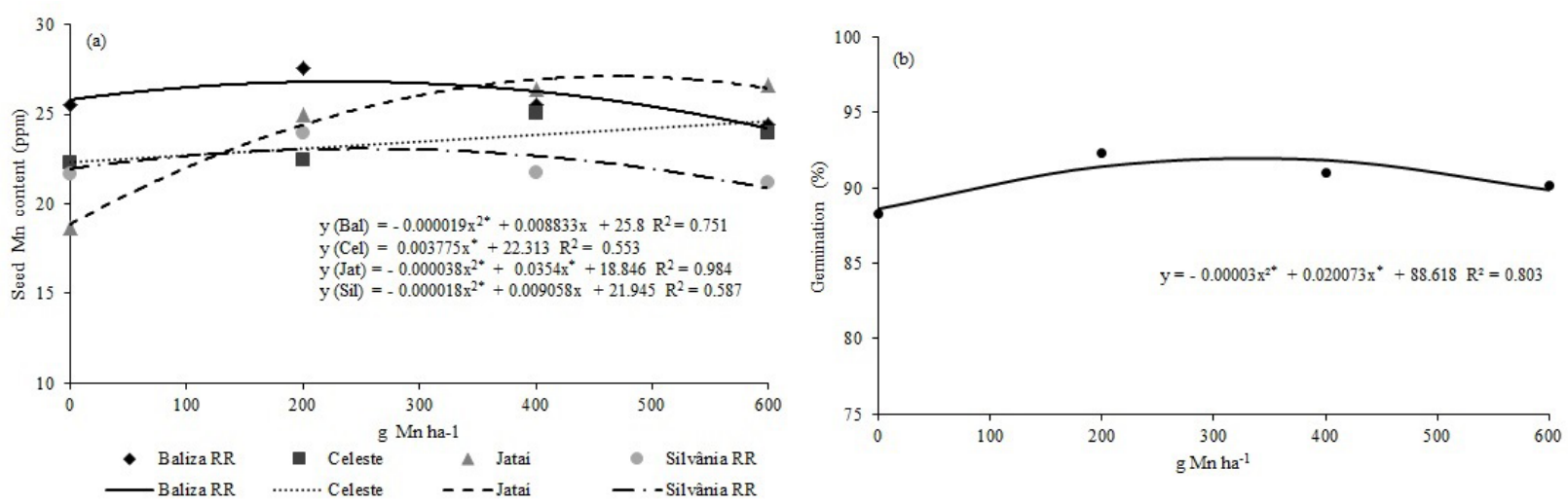

Figure 2 - Regression equation for manganese content (a) in soybean seeds as a function of doses of foliar Mn applied to plants of different cultivars and regression equation for germination (b), percentage of normal seedlings at 5 days, as a function of doses of foliar Mn applied to producer plants. *significant at 5\% probability by the $\mathrm{F}$ test.

\section{Malate dehydrogenase}

There was no difference in MDH enzyme activity in relation to the application of Mn. Among the cultivars, the greatest expression of this enzyme was observed in seeds of the cultivars Silvânia RR and Jataí (Figure 3).

In general, the physiological quality of the seeds of Baliza RR and Celeste was greater than those of Silvânia RR and Jataí (Tables 1 and 2). For the cultivars Silvânia RR and Jataí the greater expression of Malate dehydrogenase (MDH), aerobic activity, is associated with greater deterioration. Because it is an important enzyme for cellular aerobic respiratory process, this may be due to increased respiration in the seeds that were in a deteriorating process, since the enzymes involved in respiration may be activated in low-quality seeds (Shatters et al., 1994).

Malate dehydrogenase (MDH) catalyzes conversion of the malate to oxaloacetate in the Krebs cycle, producing $\mathrm{NADH}$, which is fundamental in production of ATP and of intermediate compounds essential to cell operation (Taiz; Zaiger, 2006), thus related to the aerobic respiration. Studies that relate mineral nutrition and enzyme activity in soybean seeds are scarce. In this regard, Veiga et al. (2010) did not observe differences between the activities of MDH as a result of potassium fertilization and liming. 

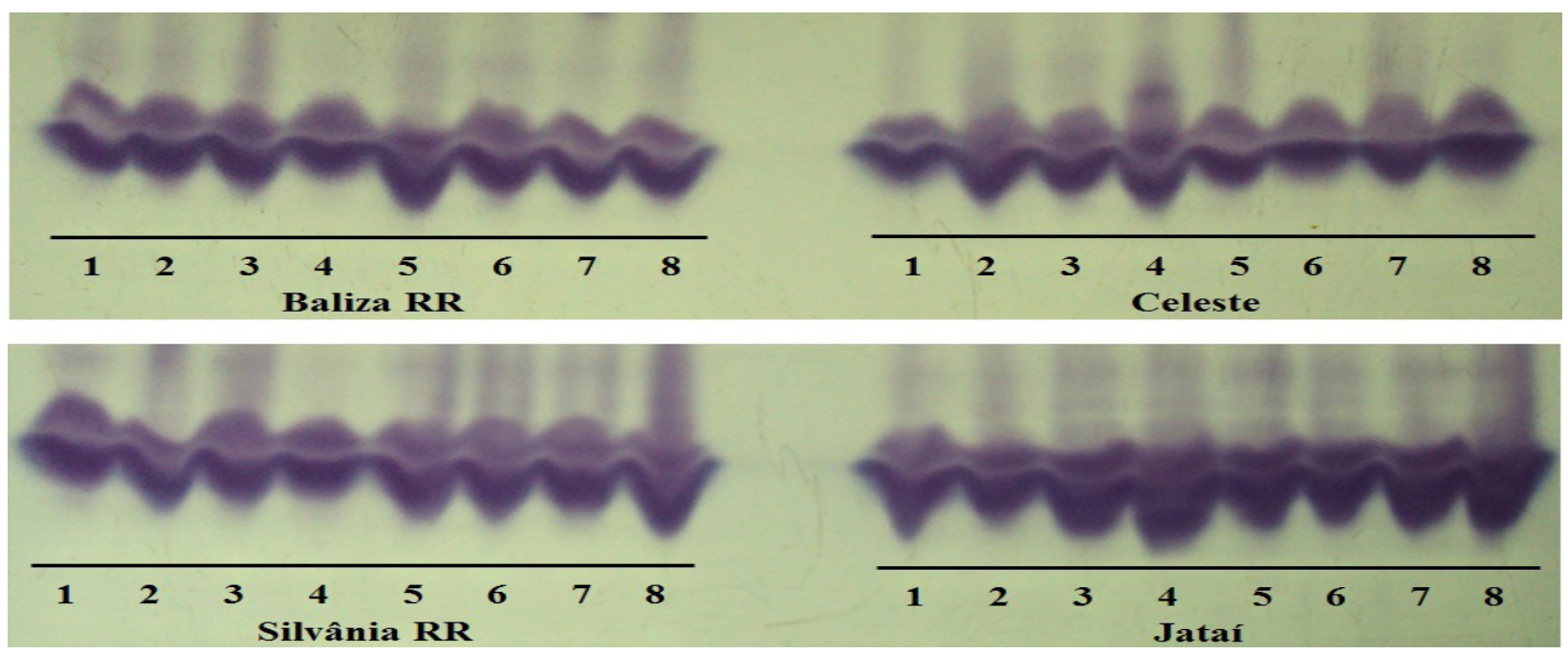

Figure 3 - Enzyme patterns of soybean seeds of the cultivars Baliza RR and Celeste, Silvânia RR and Jataí produced under different doses and stages for foliar application of $\mathrm{Mn}$, revealed for malate dehydrogenase (MDH) with: $1(0$, R1), 2(0, R3), 3 (200, R1), 4 (200, R3), 5(400, R1), 6 (400, R3), 7 (600, R1) and 8 (600 g Mn ha-1 in R3).

Table 1- Germination percentage of seeds of different soybean cultivars.

\begin{tabular}{cc}
\hline Cultivars & Germination $(\%)^{*}$ \\
\hline Baliza RR & $93 \mathrm{a}$ \\
Celeste & $90 \mathrm{~b}$ \\
Jataí & $90 \mathrm{~b}$ \\
Silvânia RR & $89 \mathrm{~b}$ \\
\hline
\end{tabular}

*Mean values followed by the same letter do not differ among themselves at $5 \%$ probability by the Scott-Knott test.

Table 2 - Emergence speed index (ESI) of seedlings of different soybean cultivars as a function of stages and doses of foliar Mn applied to seed producer plants.

\begin{tabular}{cccccc}
\hline \multirow{2}{*}{ Stages } & \multirow{3}{*}{ Cultivars } & \multicolumn{4}{c}{ Doses of foliar Mn* } \\
\cline { 3 - 5 } & Baliza RR & $13.01 \mathrm{a}$ & $13.38 \mathrm{a}$ & $13.21 \mathrm{a}$ & $13.85 \mathrm{a}$ \\
& Celeste & $12.76 \mathrm{a}$ & $13.37 \mathrm{a}$ & $12.01 \mathrm{~b}$ & $13.35 \mathrm{a}$ \\
\multirow{2}{*}{$\mathrm{R}_{1}$} & Jataí & $11.96 \mathrm{a}$ & $11.86 \mathrm{~b}$ & $11.92 \mathrm{~b}$ & $12.21 \mathrm{~b}$ \\
& Silvânia RR & $12.60 \mathrm{a}$ & $12.03 \mathrm{~b}$ & $12.00 \mathrm{~b}$ & $12.36 \mathrm{~b}$ \\
\hline \multirow{2}{*}{$\mathrm{R}_{3}$} & Baliza RR & $12.97 \mathrm{a}$ & $13.27 \mathrm{a}$ & $14.31 \mathrm{a}$ & $13.34 \mathrm{a}$ \\
& Celeste & $13.45 \mathrm{a}$ & $12.39 \mathrm{~b}$ & $12.97 \mathrm{~b}$ & $12.62 \mathrm{a}$ \\
& Jataí & $11.71 \mathrm{~b}$ & $11.98 \mathrm{~b}$ & $12.15 \mathrm{c}$ & $12.12 \mathrm{a}$ \\
& Silvânia RR & $11.60 \mathrm{~b}$ & $12.62 \mathrm{~b}$ & $11.88 \mathrm{c}$ & $12.65 \mathrm{a}$ \\
\hline
\end{tabular}

* Mean values followed by the same letter in the column do not differ among themselves at 5\% probability by the ScottKnott test. 


\section{Alcohol dehydrogenase}

Among the cultivars, greater expression of the enzyme ADH was observed in seeds of Baliza RR and Celeste (Figure 4). These cultivars, in general, exhibited seeds of greater physiological quality (Tables 1 and 2).

From the zymogram (Figure 4), a reduction in ADH enzyme activity was observed in seeds of the cultivar Celeste originating from plants subjected to the application of $400 \mathrm{~g} \mathrm{Mn} \mathrm{ha}^{-1}$ in the $\mathrm{R}_{1}$ development stage. Lower vigor values were also observed under these conditions as evaluated by the ESI test (Figure 5).

This relation between lower expression of $\mathrm{ADH}$ and low physiological quality of soybean seeds is due to the action of this enzyme. ADH reduces acetaldehyde to ethanol in anaerobic metabolism and, when the activity of this enzyme decreases, the seed is more susceptible to the deleterious action of acetaldehyde (Zhang et al., 1994), a compound which is more toxic to cells than the ethanol formed in the presence of the enzyme ADH.
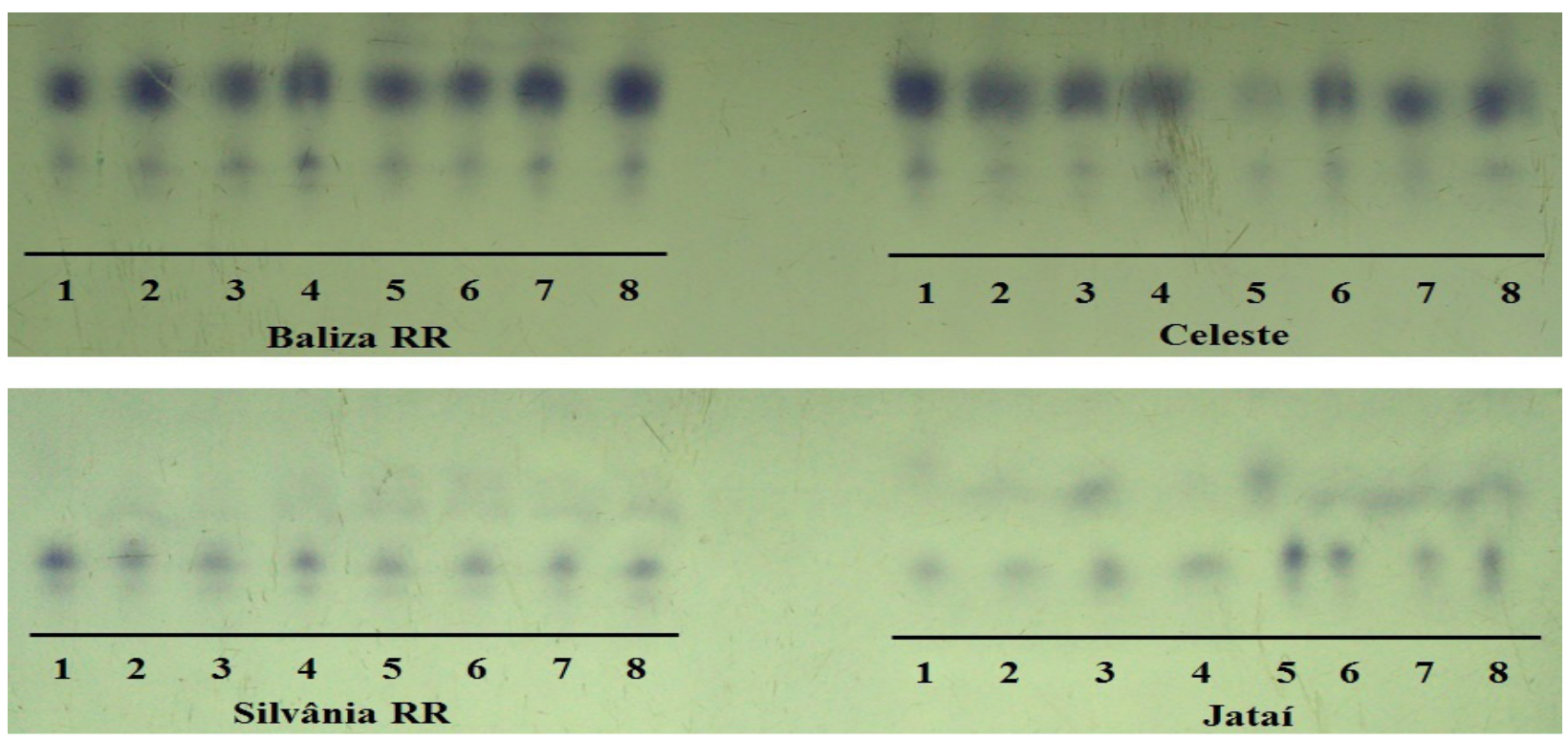

Figure 4 - Enzyme patterns of soybean seeds of the cultivars Baliza RR and Celeste, Silvânia RR and Jataí produced under different doses and stages for foliar application of Mn, revealed for alcohol dehydrogenase (ADH) with: $1(0$, R1), 2(0, R3), 3 (200, R1), 4 (200, R3), 5 (400, R1), 6 (400, R3), $7(600, \mathrm{R} 1)$ and 8 (600 g Mn ha-1 in R3).
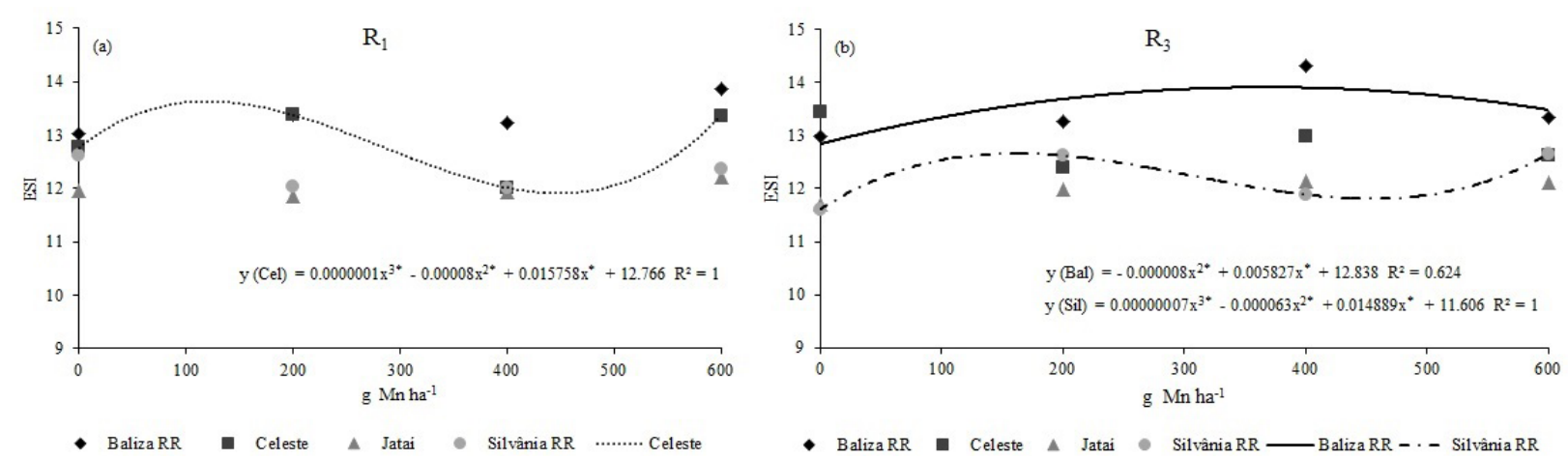

Figure 5 - Regression equation for emergence speed index (ESI) of soybean seedlings as a function of doses of foliar Mn applied to seed producer plants in different stages and cultivars. * significant at $5 \%$ probability by the $\mathrm{F}$ test. 


\section{Superoxide dismutase}

For the SOD enzyme system, differences were seen in activities as result of doses of foliar Mn, regardless of the plant development stages at the time of application of Mn (Figure 6). In general, less expression was observed in seeds produced without application of foliar Mn. As of treatment 3, with the use of Mn, an increase in SOD activity was observed.

For the seeds of the cultivars Celeste and Jataí, there was greater expression with the doses of 200 and $400 \mathrm{~g} \mathrm{Mn} \mathrm{ha}^{-1}$. For the seeds Baliza RR and Silvânia RR this increase in expression was observed mainly when the plants were subjected to the application of $\mathrm{Mn}$ at the dosage of $600 \mathrm{~g} \mathrm{Mn} \mathrm{ha}^{-1}$ (Figure 6). With the application of $600 \mathrm{~g} \mathrm{Mn} \mathrm{ha}^{-1}$, visual symptoms of phytotoxicity were observed in the leaves, which indicates a condition of stress to plants and consequently to seeds, favoring the generation of free radicals. This situation may be related to greater SOD activity at this dosage since it acts in conversion of free radicals of $\mathrm{O}_{2}{ }^{--}$to $\mathrm{H}_{2} \mathrm{O}_{2}$ and $\mathrm{O}_{2}$ (Deuner et al., 2011).

The action of enzyme systems is relevant in the process of cell detoxification because it converts the potentially toxic products of the reactive oxygen species (ROSs), among these antioxidant systems are superoxide dismutase (SOD) and peroxidase (PRX). The activation of these enzyme systems is capable of removing, neutralizing or cleaning the free radicals from the inside of the cells. Some enzymes may neutralize the action of the free radicals before damages may occur (Nkang; Omokaro; Egbe, 2000).

The greatest activity of SOD in soybean seeds as a result of foliar application of Mn may also be associated with the fact of this enzyme being oxidoreductase and being able to bond to metallic compounds, among them Mn-SOD, acting in neutralization of superoxides (Raychaudhuri, 2000). The Mn applied through the leaf translocated to the seeds and modified the micronutrient contents in them (Figure 2a). For Mn-SOD to become active, it needs $\mathrm{Mn}$ in its active site (Alscher, Erturk; Health, 2002). Gonzalez et al. (1998) reported a positive response of Mn-SOD to Mn toxicity.

\section{Peroxidase}

Differences were observed between the enzyme patterns of peroxidase (PRX) as a result of use of foliar
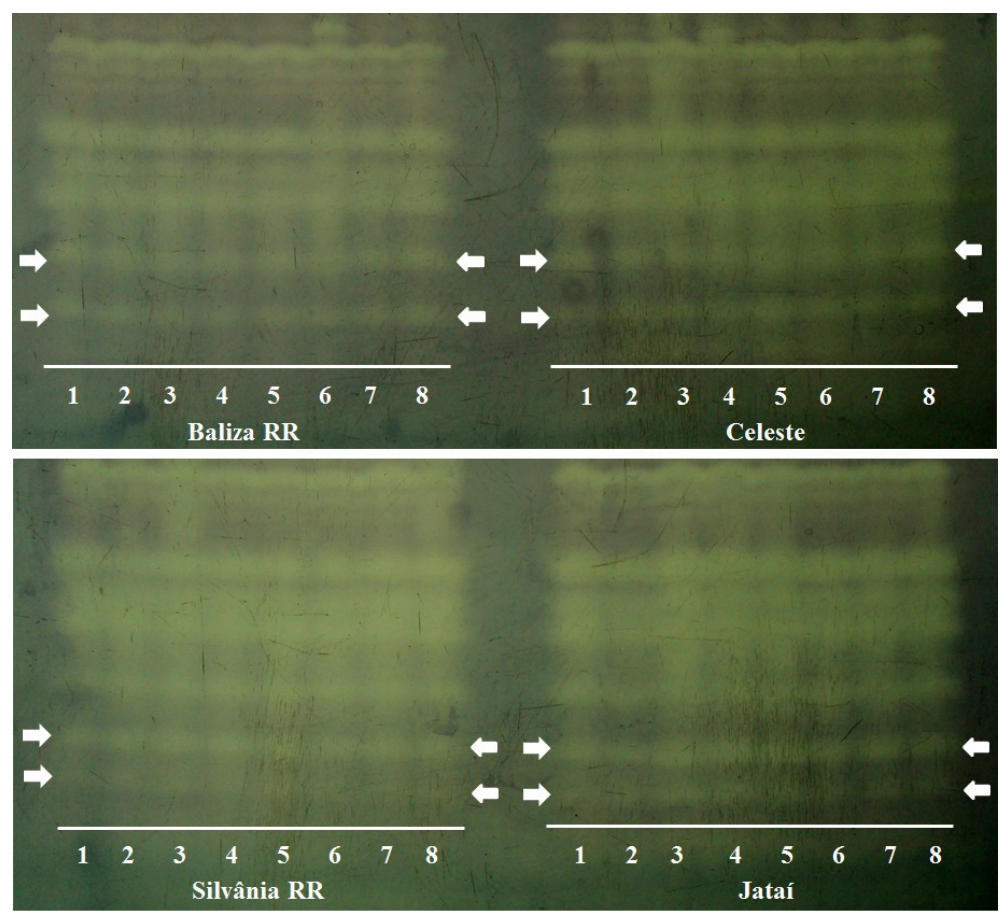

Figure 6 - Enzyme patterns of soybean seeds of the cultivars Baliza RR and Celeste, Silvânia RR and Jataí produced under different doses and stages for foliar application of $\mathrm{Mn}$, revealed for superoxide dismutase (SOD) with: $1(0, \mathrm{R} 1)$, 2(0, R3), 3 (200, R1), 4 (200, R3), 5 (400, R1), $6(400, \mathrm{R} 3), 7$ (600, R1) and 8 (600 g Mn ha ${ }^{-1}$ in R3). 
Mn in seeds of the cultivars Celeste and Silvânia RR (Figure 7). For the cultivar Celeste, with the application of $600 \mathrm{~g} \mathrm{Mn} \mathrm{ha}^{-1}$ in the $\mathrm{R}_{3}$ stage and for Silvânia RR with the use of the same dose in $R_{1}$, greater expressions of PRX were observed. This may be related to the phytotoxicity observed with the use of this dose because the plants respond to the increase of the reactive oxygen species (ROSs) with acceleration of the enzymatic and non-enzymatic antioxidant processes (Alscher, Erturk; Health, 2002). The peroxidase enzyme system is relevant among the antioxidant systems because it degrades the $\mathrm{H}_{2} \mathrm{O}_{2}$ formed by the SOD.

One way of defense to stress is the oxidation of $\mathrm{Mn}^{+2}$ to $\mathrm{Mn}^{+3}$ in vivo, for the purpose of paralyzing free radicals. One of the hypotheses is that peroxidase may cause enzymatic oxidation of Mn (Hewitt; Nicholas, 1963) by the mechanism $\mathrm{H}_{2} \mathrm{O}_{2}+2 \mathrm{H}^{+}+2 \mathrm{Mn}^{2+}$ to $2 \mathrm{Mn}^{3+}$ $+2 \mathrm{H}_{2} \mathrm{O}$. However, supplemental research is necessary for the purpose of relating stress in plants and biochemical alterations in the seeds produced.

Among the cultivars in general, greater activities of PRX were observed in seeds of Silvânia RR and Jataí (Figure 7). Inferior physiological quality was observed in seeds of Silvânia RR and Jataí (Tables 1 and 2), which may be associated with greater activity of the PRX enzyme system due to the high levels of reactive oxygen species. High concentrations of reactive oxygen species cause oxidative damages and, in the first stage, there is an increase in the enzymatic and non-enzymatic antioxidant processes for maintenance of this species at non-toxic levels (Alscher, Erturk; Health, 2002; Ben Amor et al., 2005; Moller, Jensen; Hansson, 2007).

\section{Isocitrate lyase}

In seeds of the cultivars Baliza RR, Celeste and Jataí, differences were seen in the isocitrate lyase profiles (ICL) in relation to the application of foliar Mn (Figure 8). In Baliza RR and Celeste seeds, greater activities were observed in the treatments with $600 \mathrm{~g} \mathrm{Mn} \mathrm{ha}^{-1}$; however, only in Baliza RR seeds greater activity was observed in seeds in the absence of Mn application. For Jataí seeds, like that which was observed for Baliza RR and Celeste, greater expression of ICL was also with $600 \mathrm{~g} \mathrm{Mn} \mathrm{ha}^{-1}$, only in $\mathrm{R}_{3}$ (Figure 8 ).

Among the cultivars, Baliza RR and Celeste seeds exhibited greater ICL activity in comparison to those of Silvânia RR and Jataí upon considering all the treatments (Figure 8). Lower expression of ICL was observed in seeds of the cultivar Silvânia RR, which may be associated with the lower physiological quality of the seeds of this cultivar (Tables 1 and 2). In the seeds of the cultivar Baliza RR, which exhibited better physiological quality (Tables 1 and 2), greater ICL activity was observed (Figure 8).
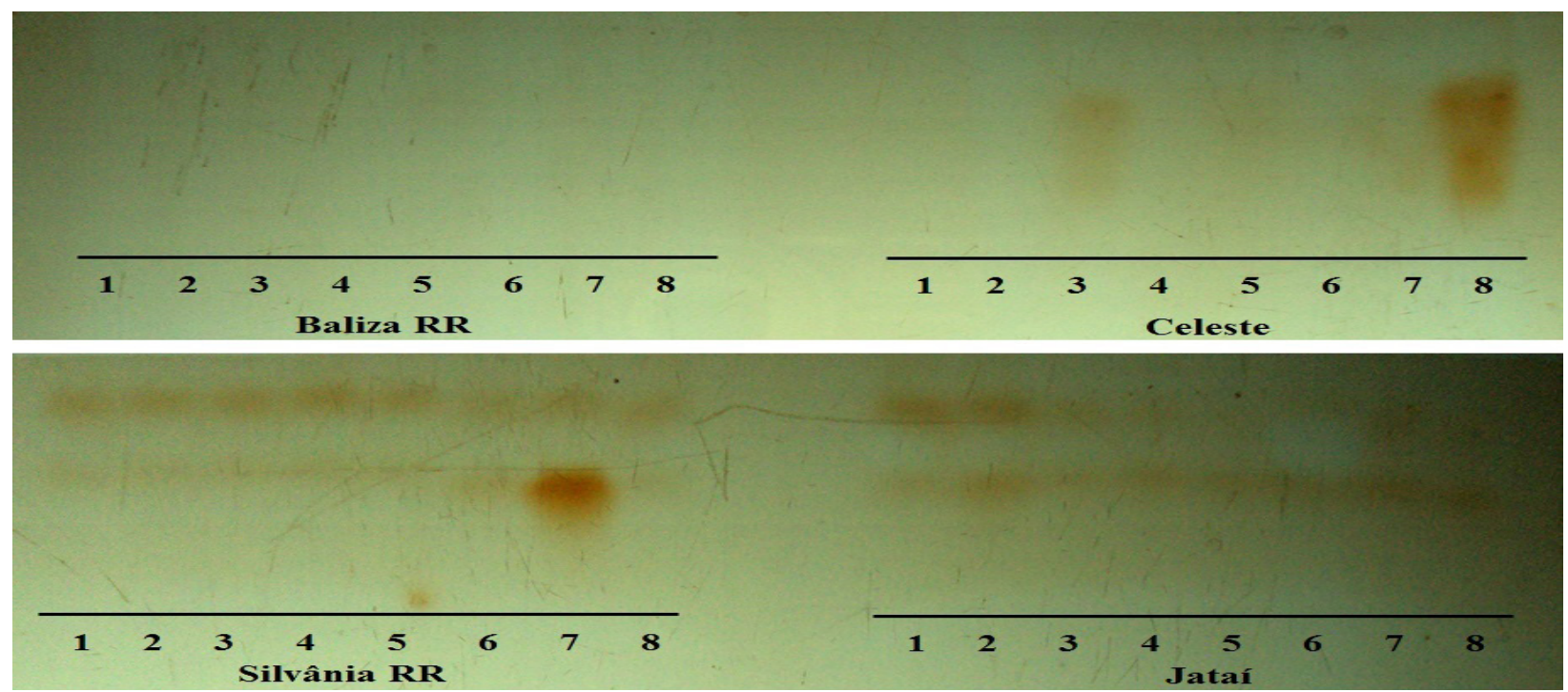

Figure 7 - Enzyme patterns of soybean seeds of the cultivars Baliza RR and Celeste, Silvânia RR and Jataí produced under different doses and stages for foliar application of $\mathrm{Mn}$, revealed for peroxidase (PRX) with: 1(0, R1), 2(0, R3), 3 (200, R1), 4 (200, R3), 5 (400, R1), 6 (400, R3), 7 (600, R1) and 8 (600 g Mn ha' ${ }^{-1}$ in R3). 

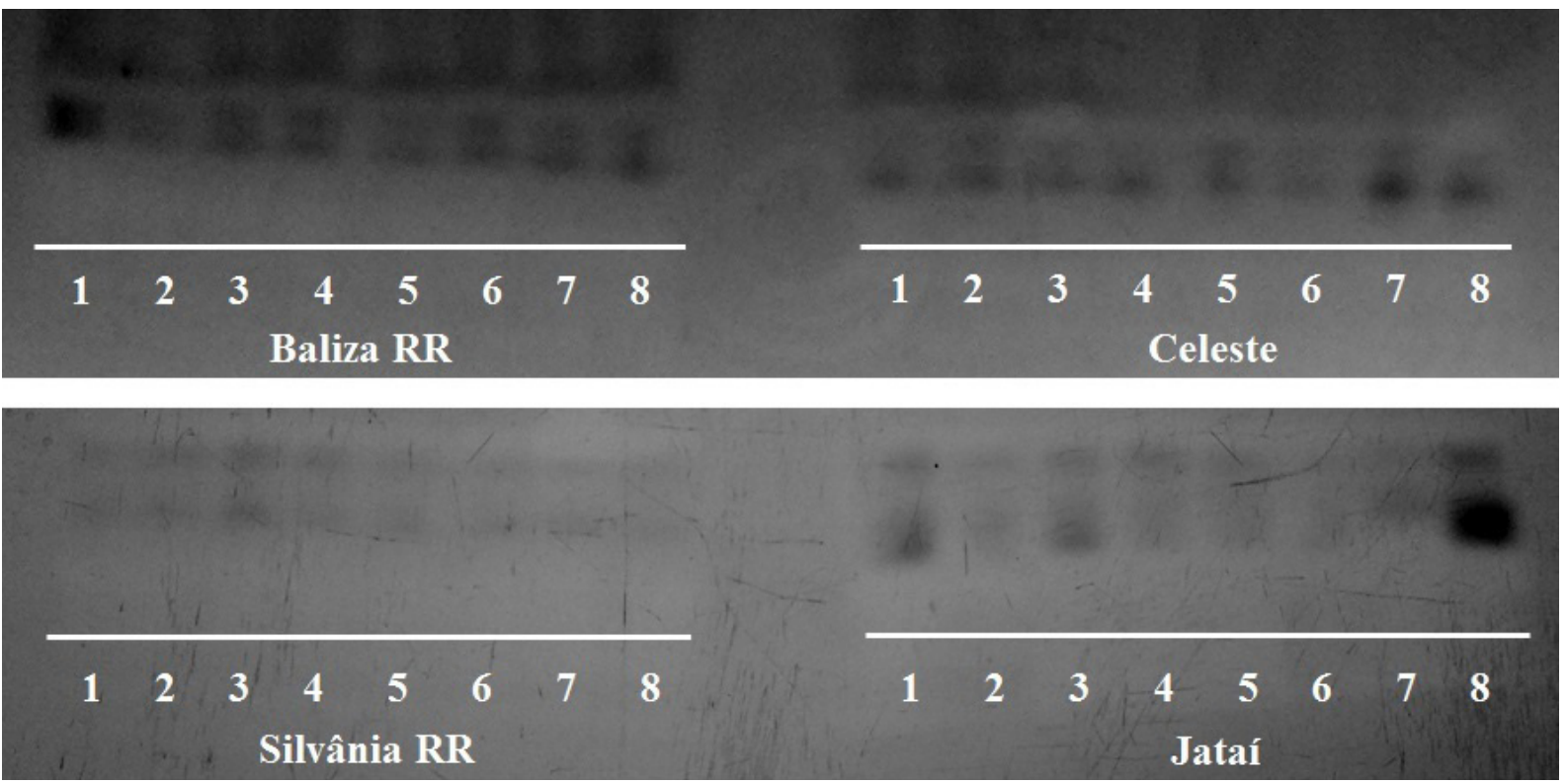

Figure 8 - Enzyme patterns of soybean seeds of the cultivars Baliza RR and Celeste, Silvânia RR and Jataí produced under different doses and stages for foliar application of Mn, revealed for isocitrate lyase (ICL) with: 1(0, R1), 2(0, R3), 3 (200, R1), 4 (200, R3), 5 (400, R1), 6 (400, R3), 7 (600, R1) and 8 (600 g Mn ha-1 in R3).

ICL participates in the glyoxylate cycle, in the glyoxysomes, involved in the metabolism of lipids stored in the oilseeds, as in the case of soybeans. The activity of this enzyme increases during germination of the seeds, obtaining maximum values at the peak of degraded lipids which are converted into sucrose (Bewley; Black, 1994). Martins et al. (2000) observed the importance of ICL and of the glyoxylate cycle for the germination process in soybean seeds and also greater ICL activity in seeds of the Doko cultivar in relation to CAC-1. It is worth noting that seeds of the Doko cultivar tend to show high physiological quality (Braccini et al., 1994; Braccini et al., 1998; MartinsFilho et al., 2001).

\section{CONCLUSIONS}

Expression of the enzymes esterase, superoxide dismutase, peroxidase and isocitrate lyase in soybean seeds is affected by foliar application of Mn regardless plant development stage $\left(\mathrm{R}_{1}\right.$ or $\left.\mathrm{R}_{3}\right)$.

In the seeds of the cultivars that exhibit better physiological quality, Celeste and Baliza RR, greater expressions of the enzymes alcohol dehydrogenase and isocitrate lyase and lower expressions of malate dehydrogenase and peroxidase are observed in relation to the cultivars with seeds of inferior physiological quality, Jataí and Silvânia RR.

\section{ACKNOWLEDGMENTS}

Authors recognize their gratitude to CAPES (Coordination of Improvement of Higher Education Personnel), FAPEMIG (Research Foundation of Minas Gerais State) and CNPq (National Research and Development Council) for their financial support and scholarships.

\section{REFERENCES}

\section{ALFENAS, A. C. (Ed.). Eletroforese e marcadores} bioquímicos em plantas e microrganismos. 2. ed. Viçosa, MG: UFV, 2006. 627 p.

ALSCHER, R. G.; ERTURK, N.; HEALTH, L. S. Role of superoxide dismutases (SODs) in controlling oxidative stress in plants. Journal of experimental Botany. 53(372):1331-1341, 2002.

ÁVILA, M. R. et al. Physiological quality, content and activity of antioxidants in soybean seeds artificially aged. Revista Brasileira de Sementes. 34(3):397-407, 2012.

BEN AMOR, N. et al. Physiological and antioxidant responses of the perennial halophyte Crithmum maritimum to salinity. Plant Science.168:889-899, 2005. 
BEWLEY, J. D.; BLACK, M. Seeds physiology of development and germination. New York: Plenum, 1994. $445 \mathrm{p}$.

BRACCINI, A. L. et al. Avaliação da qualidade fisiológica e sanitária da semente de genótipos de soja (Glycine max (L.) Merrill) com diferentes graus de impermeabilidade do tegumento. Revista Brasileira de Sementes. 16(2):195-200, 1994.

Influência do potencial hídrico induzido por polietilenoglicol na qualidade fisiológica de sementes de soja. Pesquisa Agropecuária Brasileira. 33(9):14511459, 1998.

BRASIL. Ministério da Agricultura, Pecuária e Abastecimento. Regras para análise de sementes. Brasília, 2009. 395 p.

DANTAS, A. A. A.; CARVALHO, L. G.; FERREIRA, E. Classificação e tendências climáticas em Lavras, MG. Ciência e Agrotecnologia. 31(6):1862-1866, 2007.

DECHEN, A. R.; NACHTIGALL, G. R. Micronutrientes. In: FERNANDES, M. S. (Ed.). Nutrição Mineral de Plantas. Viçosa, MG: Sociedade Brasileira de Ciência do Solo, 2006. p. 327-354.

DEUNER, C. et al. Viabilidade e atividade antioxidante de sementes de genótipos de feijão-miúdo submetidos ao estresse salino. Revista Brasileira de Sementes. 33(4):711-720, 2011.

EL-SHABRAWI, H. et al. Redox homeostasis, antioxidant defense, and methylglyoxal detoxification as markers for salt tolerance in Pokkali rice. Protoplasma. 245(1-4):85-96, 2010.

FEHR, W. R. et al. Stage of development descriptions for soybeans, Glycine max (L.) Merril. Crop Science. 11(6):929-931, 1971.

FERREIRA, D. F. Sisvar: a computer statistical analysis system. Ciência e Agrotecnologia. 35(6):1039-1042, 2011.

FORMAN, H. J.; MAIORINO, M.; URSINI, F. Signaling functions of reactive oxygen species. Biochemistry. 49(5):835-842, 2010.
GRIS, C. F. et al. Qualidade fisiológica e teor de lignina no tegumento de sementes de soja convencional e transgênica RR submetidas a diferentes épocas de colheita. Ciência e Agrotecnologia. 34(2):374-381, 2010.

HEWITT, E. J.; NICHOLAS, D. J. D. Metabolic inhibitors. In: HOCHSTER, R. M.; UASTEL, J. H. (Ed.). Metabolic inhibitors a comprehensive treatise. New York: Academic, 1963. v. 1.

KOLCHINSKI, E. M.; SCHUCH, L. O. B.; PESKE, $\mathrm{S}$. T. Seeds vigor and intra-specific competition in soybean. Ciência Rural. 35(6):1248- 256, 2005.

MAGUIRE, J. D. Speed of germination aid in selection and evaluation for seedling and vigour. Crop Science. 2(2):176-177, 1962.

MALAVOLTA, E. Manual de nutrição mineral de plantas. São Paulo: Agronômica Ceres, 2006. 638 p.

MALAVOLTA, E.; VITTI, G. C.; OLIVEIRA, S. A. Avaliação do estado nutricional da planta: princípios e aplicações. 2. ed. Piracicaba: Potafos, 1997. 319 p.

MANN, E. N. et al. Efeito da aplicação de manganês no rendimento e na qualidade de sementes de soja. Pesquisa Agropecuária Brasileira. 37(12):17571764, 2002.

MARTINS, C. A. O. et al. Atividade da isocitrato-liase durante a germinação de sementes de soja. Revista Brasileira de Sementes. 22(1):42-46, 2000.

MOLLER, I. M.; JENSEN, P. E.; HANSSON, A. Oxidative modifications to cellular components in plants. Annual Review of Plant Biology. 58:459-481, 2007.

MONDO, V. H. V. et al. Spatial variability of soil fertility and its relationship with seed physiological potential in a soybean production area. Revista Brasileira de Sementes. 34(2):193-201, 2012.

MARTINS-FILHO, S. C. et al. Avaliação da qualidade fisiológica de sementes de soja armazenadas em condições de ambiente natural em Alegre-ES. Revista Brasileira de Sementes. 23(2):201-208, 2001. 
NKANG, A.; OMOKARO, D.; EGBE, A. Effects of desiccation on the lipid peroxidation and activities of peroxidase and polyphenoloxidase in seeds of Telfairia occidentalis. Seed Science and Technology. 28(1):1-9, 2000.

RAYCHAUDHURI, S. S. The role of superoxide dismutase in combating oxidative stress in higher plants. The Botanical Review. 66:89-98, 2000.

RIBEIRO, A. C.; GUIMARÃES, P. T. G.; ALVAREZ, V. V. H. (Ed.). Recomendação para o uso de corretivos e fertilizantes em Minas Gerais: $5^{\text {a }}$ aproximação. Viçosa, MG: Comissão de Fertilidade do Solo do Estado de Minas Gerais, 1999. 359 p.

SCHEEREN, B. R. et al. Qualidade fisiológica e produtividade de sementes de soja. Revista Brasileira de Sementes. 32(3):35-41, 2010.
SHATTERS, R. G. JR. et al. Soybean seed deterioration and response to priming: changes in specific enzyme activities in extracts from dry and germinating seeds. Seed Science Research. 4:33-41, 1994.

TAIZ, L.; ZEIGER, E. Energy and Enzymes. In: Plant physiology. 4th ed. Sunderland: Sinauer Associates, 2006. chap. 2, p. 1-22.

VEIGA, A. D. et al. Influência do potássio e da calagem na composição química, qualidade fisiológica e na atividade enzimática de sementes de soja. Ciência e Agrotecnologia. 34(4):953-960, 2010.

ZHANG, M. et al. A mechanism of seed deterioration in relation to volatile compounds evoked by dry seeds themselves. Seed Science Research. 4(1):49-56, 1994. 